Diabetologia 7, 195-203(1971)

(C) by Springer-Verlag 1971

\title{
Inhibition of Intestinal Absorption and Improvement of Oral Glucose Tolerance by Biguanides in the Normal and in the Streptozotocin-Diabetic Rat
}

\author{
E. LoRCH \\ Department of Experimental Medicine, F. Hoffmann-La Roche \& Co. Ltd., Basle, Switzerland \\ Received: August 8, 1970, accepted: March 3, 1971
}

Summary. In the rat the assumption of a primary effect of moderate doses of biguanides on intestinal $a b$ sorption is supported by the following results: 1 . The tolerance to parenteral glucose administration was not improved. - 2. After oral pretreatment the hyperglycaemia induced by oral glucose was decreased. -3 . After pretreatment in vivo the transport of glucose through the intestinal wall was inhibited. -4 . The intestinal glucose transport was inhibited also in vitro in the presence of biguanides at concentrations to be expected in intestinal tissue in vivo after efficient doses. $-\mathbf{5}$. In the streptozo. tocin-diabetic rat there was a strong correlation between the feeding state and the hypoglycaemic effect of biguanides. In streptozotocin-diabetic rats previously starved and then refed, the hypoglycaemic effect decreased with decreasing doses of the diabetogenic agent. -6 . The relative potency of various biguanides was similar with regard to their effects on hyperglycaemia and on the intestinal glucose transport. - The results suggest, however, that in the rat further events, probably triggered by the inhibition of intestinal absorption, are involved in the mechanism of action of biguanides.

Inhibition de l'absorption intestinale et amélioration de la tolérance orale au glucose avec des biguanides chez le rat normal et chez le rat rendu diabétique par le streptozotocine

Résumé. Les constatations suivantes permettent la conclusion que l'application de faibles doses de biguanides influence chez le rat premièrement l'absorption intestinale: 1. Aucune amélioration de la tolérance parentérale au glucose. 2. Après un prétraitement oral l'hyperglycémie induite par l'administration orale de glucose est diminuée. - 3. Après un prétraitement in vivo le transport de glucose par la paroi intestinale est freiné. 4. Des concentrations de biguanides que l'on pourrait rencontrer in vivo dans le tissu intestinal (après traitement avec des dosages efficaces) provoque également une inhibition du transport de glucose dans l'intestin in vitro. 5. Chez le rat rendu diabétique par streptozotocine il existe une forte corrélation entre l'alimentation et l'effet hypoglycémique. Chez le rat réalimenté l'effet hypogly. cémique diminue après l'administration de doses décrois santes de l'agent diabétogène. - 6. La puissance relative de divers biguanides par rapport à la diminution de l'hypoglycémie et l'inhibition du transport intestinal de glucose peut être comparée. - Les résultats trouvés chez le rat font cependant allusion au fait que l'inhibition de l'absorption intestinale n'est pas la seule action des biguenides. Il semble qu'il y a encore d'autres facteurs reliés à cette inhibition.

Hemmung der intestinalen Glucoseresorption und Verbes. serung der oralen Glucosetoleranz durch Biguanide bei normalen und Streptozotocin-diabetischen Ratten

Zusammenfassung. Folgende Befunde lassen darauf schließen, daß Biguanide in mäßiger Dosierung bei der Ratte primär die intestinale Absorption beeinflussen: 1 . Die parenterale Glucosetoleranz wurde nicht verbessert. - 2. Nach oraler Vorbehandlung wurde die durch orale Glucosegabe induzierte Hyperglykämie vermindert. 3. Nach In-vivo-Vorbehandlung war der Glucosetransport durch die Darmwand gehemmt. - 4. Der intestinale Glucosetransport wurde auch in vitro in Gegenwart von Biguanid-Konzentrationen gehemmt, die man im intestinalen Gewebe nach Applikation wirksamer Dosen erwar. ten kann. - 5. In der Streptozotocin-diabetischen Ratte bestand eine strenge Korrelation zwischen Fütterungszustand und hypoglykämischem Effekt. In ,,wiedergefütterten" Streptozotocin-Ratten nahm die hypoglykämi. sche Wirkung mit abnehmenden Dosen des diabetogenen Agens ab. -6 . Die relative Wirkungsstärke verschiedener Biguanide bezüglich Verminderung der Hyperglykämie und Hemmung der intestinalen Gilucoseaufnahme war vergleichbar. - Die erhobenen Befunde deuten jedoch darauf hin, daß in der Ratte zusätzliche Vorgänge, die möglicherweise durch die Absorptionshemmung ausgelöst werden, am Wirkungsmechanismus der Biguanide wesentlich beteiligt sind.

Key-words: Biguanides, glucose-tolerance, intestinal absorption, streptozotocin-diabetic rat, salicylate.

\section{Introduction}

In order to explain the antidiabetic properties of biguanides several mechanisms have been discussed, i.e. direct effects upon the glucose metabolism (Butterfield and Whichelow, 1962; Krüger et al., 1960; Staub, 1928; Williams et al., 1957), augmentation of insulin action in various tissues (Butterfield et al., 1963; Creutzfeldt et al., 1963; Daweke and Bach, 1963; Ditschuneit and Hoff, 1964) and, more recently, the inhibition of intestinal sugar absorption (Berger, 1968; Biro et al., 1961; Czyzyk and Lawecki, 1965; Czyzyk et al., 1968; Hollobaugh et al., 1967; Hollobaugh et al., 1970; Krüger et al., 1970). The absorption theory offers the most plausible explanation of why biguanides diminish in the human (Hollobaugh et al., 1970; Gomez et al., 1969) and in the dog (Czyzyk et al., 1968) the hyperglycaemic response to an oral (or intraduodenal) glucose load whereas they do not affect the intravenous glucose tolerance. 
To our knowledge no attempt has been made to correlate the action of biguanides on glucose tolerance and on intestinal absorption in an identical species. Therefore, the effects of biguanides in normal rats were compared using the following parameters: oral and parenteral glucose tolerance as well as glucose transport through everted intestinal sacs (after pretreatment of intact animals and after addition of the biguanides in vitro). In order to check the involvement of insulin in the mechanism of biguanide action, experiments were also carried out with streptozotocin-diabetic rats.

\section{Methods}

Randomized male albino rats from a closed colony (Füllinsdorf/BL, Switzerland) were kept on a commercial diet (pellets No. 194, Nafag Ltd., Gossau SG, Switzerland). Streptozotocin-diabetes (Junod et al., 1969) was induced by subcutaneous injection of $60 \mathrm{mg} / \mathrm{kg}$ (unless otherwise stated) of synthetic streptozotocin (Hardegger et al., 1969) into animals fasted for $24 \mathrm{~h}$. Experiments with diabetic animals were usually performed one week later, when the animals showed all the symptoms of severe diabetes, i.e. very low levels of immunoreactive insulin, hyperglycaemia, glucosuria, ketonuria, polydipsia, polyuria and loss of body weight.

The compounds were administered as aqueous solution of hydrochloride (biguanides) or as the sodium salt (salicylate) either per stomach tube $(5 \mathrm{ml} / \mathrm{kg}$ ) or intraperitoneally $(2.5 \mathrm{ml} / \mathrm{kg})$. Heparinized plasma obtained after decapitation was deproteinized (Somogyi, 1945), and glucose was determined by the glucose oxidase method adapted to the Technicon Autoanalyzer (Watson, 1962). Urinary glucose was measured similarly after interfering material had been removed with Amberlite MB-3 resin (Logan and Haight, 1965).
Ketonuria was estimated by Acet-Test tablets (Ames). Glycogen was estimated after saponification of the liver samples (obtained by the freeze - stop technique), precipitation with ethanol (Good et al., 1933) and. enzymatic hydrolysis to glucose (Johnson et al., 1963).

The intestinal transport of glucose was studied using the everted sac preparation of Wilson and Wiseman (1954). The ileum of rats starved. for $72 \mathrm{~h}$ and anaesthetized with ether, was rinsed thoroughly in situ with oxygenated $0.9 \% \mathrm{NaCl}$ of $37^{\circ} \mathrm{C}$. Three pieces of the everted proximal ileum (each about $40 \mathrm{~mm}$ in length) were filled with $0.6 \mathrm{ml}$ Krebs-Ringerbicarbonate buffer, $\mathrm{pH}$ 7.4, gassed with $95 \%$ $\mathrm{O}_{2}-5 \% \mathrm{CO}_{2}$, containing $50 \mathrm{mg}$ of glucose per $100 \mathrm{ml}$. The outer, i.e. mucosal incubation medium consisted of $10 \mathrm{ml}$ of the buffer containing the same concentra. tion of glucose and the test compounds.

Incubations were carried out in triplicate (using a randomized distribution of sacs from several animals) with shaking (30-40 cycles/minute) at $37^{\circ} \mathrm{C}$ under $95 \% \mathrm{O}_{2}-5 \% \mathrm{CO}_{2}$ in $50 \mathrm{ml}$ Erlenmeyer Alasks sealed with serum caps. The increase in glucose concentration in the serosal fluid was determined after one hour. Without correction for small changes in volume in the serosal fluid or for the decrease in glucose concentration in the mucosal medium, the inhibition of glucose transport was expressed in percent compared with the transport in controls (about $5 \mu \mathrm{mol} / \mathrm{sac} / \mathrm{hour}$ ).

\section{Results}

\section{A. Effects of biguanides on blood glucose homeostasis}

1. Normal Rats. The repeated oral administration of n-butylbiguanide (which was well tolerated) had no significant effect on the fasting and postprandial plasma glucose level of normal rats (Table 1). In contrast, intra-peritoneal injection of the same doses into

Table 1. Plasma glucose and liver glycogen of rats after oral administration of n-butylbiguanide

$$
\text { n-Butylbigua- Normal rats Diabetic rats }
$$

$(\mu \mathrm{mol} / \mathrm{kg}) \quad$ starved $\quad$ refed $\quad$ starved $\quad$ refed

(a)

5 Applications of biguanide $(48,40, \quad 300$

24,16 and $2 \mathrm{~h}$ prior to the glucose

Plasma glucose ( $\mathrm{mg} / 100 \mathrm{ml}$; means of 5 rats \pm S.E.M.) determination)

\begin{tabular}{|c|c|c|c|c|c|}
\hline $\begin{array}{l}\text { (b) } \\
1 \text { Application of biguanide } \\
\text { (2 h prior to the glucose and/or } \\
\text { glycogen determination) }\end{array}$ & $\begin{array}{r}0 \\
100 \\
300 \\
0 \\
300\end{array}$ & $\begin{array}{l}93 \pm 10 \\
90 \pm 12 \\
101 \pm 13 \\
\text { liver glycogen } \\
0.50 \pm 0.02 \\
0.46 \pm 0.03\end{array}$ & $\begin{array}{c}136 \pm 4 \\
139 \pm 3 \\
153 \pm 16 \\
(m g / 100 \mathrm{mg} \text { wet } \\
14.8 \pm 0.7 \\
11.3 \pm 0.8^{\mathrm{b}}\end{array}$ & $\begin{array}{c}132 \pm 11 \\
141 \pm 13 \\
119 \pm 11 \\
\text { liver; means of } 10 \\
0.62 \pm 0.03 \\
0.52 \pm 0.03\end{array}$ & 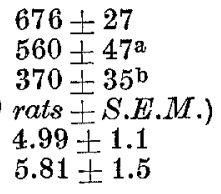 \\
\hline
\end{tabular}

Body weight of animals: $180-220 \mathrm{~g}$;

starvation (a): $48 \mathrm{~h}$; (b) $40 \mathrm{~h}$;

refeeding: $16 \mathrm{~h}$ after (a) $32 \mathrm{~h}$ or (b) $24 \mathrm{~h}$ of starvation.

Diabetes was induced as described in methods one week before the experiment.

a $p<0.05$

b $p<0.01$ (significance of differences between control and treated group). In normal rats similar results were obtained 1 and $3 \mathrm{~h}$ after $\mathrm{n}$-butylbiguanide (not shown). 
starved animals caused severe hypoglycaemia (Fig. 1), but at this dose level $40-60 \%$ of the animals died within $24 \mathrm{~h}$ after the third injection. considerably improved after oral but not after i.p. administration of the biguanide. It is noteworthy that after glucose ingestion the maximum glucose con-

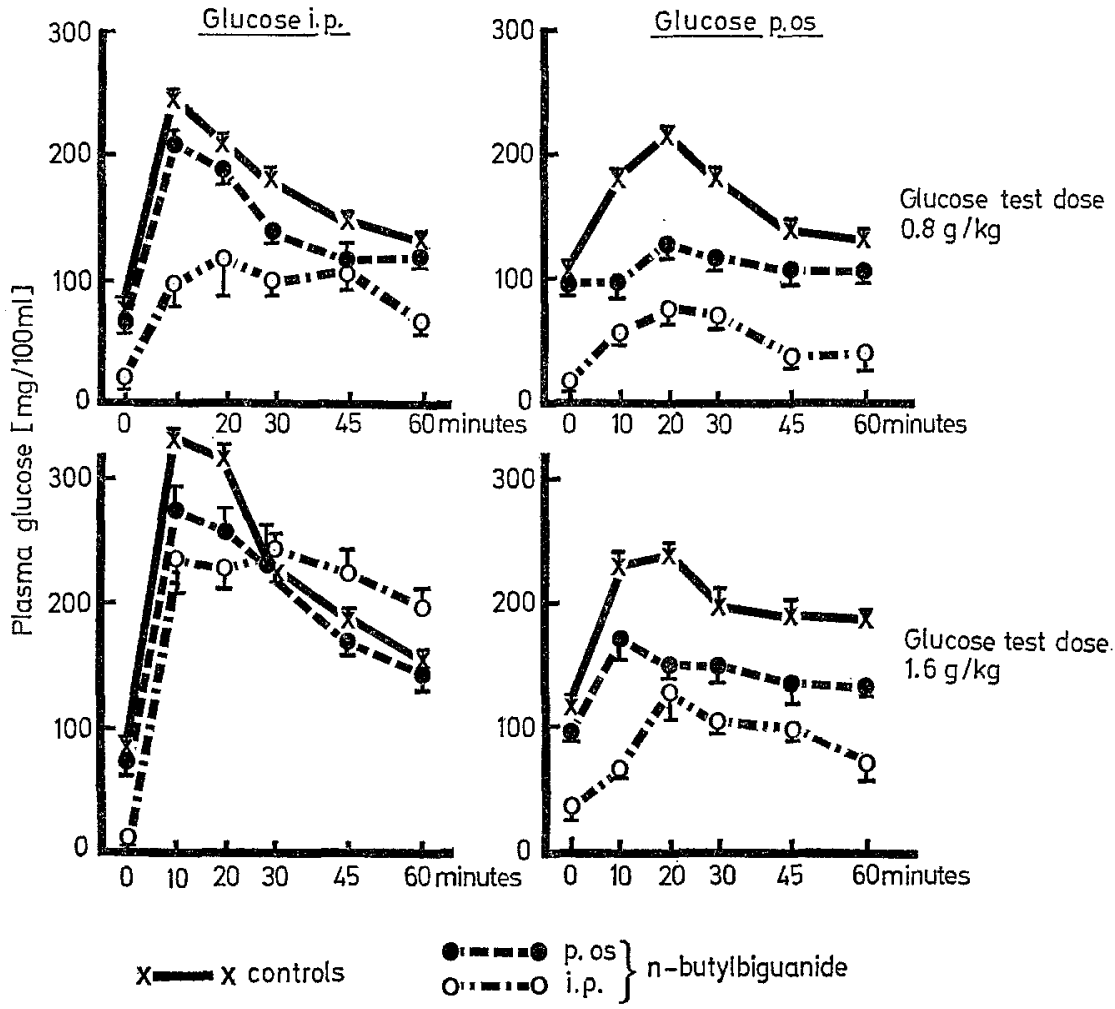

Fig. 1. Plasma glucose after parenteral and oral glucose loads in rats pretreated with n-butylbiguanide Normal rats $(150-180 \mathrm{~g})$ received 3 doses of $300 \mu \mathrm{mol} / \mathrm{kg}$ of $\mathrm{n}$-butylbiguanide 25,17 and $1 \mathrm{~h}$ before glucose. Food was withdrawn before the first administration. Abscissa: Time after glucose loading. Ordinate: Plasma glucose concentration of animals (mean \pm S.E.M.); number of animals: $N=5$ in treated groups; $N=10$ in control groups

The tolerance to parenterally administered glucose was not improved after administration by either route (Tables 2 and 3 ). The tolerance to oral glucose was

Table 2. Cumulative hyperglycaemic response ${ }^{1}$ to glucose in rats starved for 40 h after pretreatment with $n$-butylbiguanide $(3 \times 300 \mu \mathrm{mol})$

(Experimental conditions see Fig. 1).

\begin{tabular}{llll}
\hline Glucose & & \multicolumn{2}{l}{$\begin{array}{l}\text { Pretreated with n-butyl- } \\
\text { biguanide }\end{array}$} \\
\cline { 1 - 2 } $\mathrm{g} / \mathrm{kg}$ & $\begin{array}{l}\text { administra- } \\
\text { tion }\end{array}$ & i.p. & per os \\
\hline 0.8 & i.p. & \multicolumn{2}{l}{ in $\%$ of controls } \\
1.6 & & $103 \pm 9$ & $97 \pm 7$ \\
\hline 0.8 & per os & $70 \pm 13$ & $29 \pm 19^{\mathrm{b}}$ \\
1.6 & & $72 \pm 14$ & $49 \pm 4^{\mathrm{c}}$ \\
\hline
\end{tabular}

${ }^{1}$ Integrated plasma glucose values above initial level during the period of observation.

Significance of differences between treated and control group:

$$
{ }^{\mathrm{a}} p<0.05 \quad{ }^{\mathrm{b}} p<0.02 \quad{ }^{\mathrm{c}} p<0.001
$$

centration of the plasma was not reached later than in controls (Fig. 1). The maximum effect on plasma glucose after an oral glucose load of $0.8 \mathrm{~g} / \mathrm{kg}$ was observed $2 \mathrm{~h}$ after the single administration of n-butylbiguanide (1000 $\mu \mathrm{mol} / \mathrm{kg}$, per os) (Fig. 2). The degree of inhibition was dose-dependent for n-butylbiguanide and other biguanides (Fig. 3).

Table 3. Approximative $K$-values ${ }^{1}$ after parenteral glucose administration

(Experimental conditions see Fig. 1).

\begin{tabular}{llll}
\hline $\begin{array}{l}\text { Glucose } \\
\text { g/kg }\end{array}$ & Controls & $\begin{array}{l}\text { Pretreated with n-butyl- } \\
\text { biguanide } \\
\text { i.p. }\end{array}$ & per os \\
\hline 0.8 & 1.48 & \}$<0.5$ & 1.33 \\
1.6 & 1.52 & \} & 1.31 \\
\hline
\end{tabular}

1 Coefficient of glucose assimilation

$$
K=-\frac{\ln \mathrm{C}_{1}-\ln \mathrm{C}_{2}}{t_{2}-t_{1}} \times 100 ;
$$

$\mathrm{C}_{1}$ : plasma glucose conc. at time $t_{1}$ $\mathrm{C}_{2}$ : plasma glucose conc. at time $t_{2}$ 
2. Diabetic Rats. Diabetic rats starved for $40 \mathrm{~h}$ showed only slightly elevated plasma glucose levels. In these animals, as in normal rats, moderate doses of biguanides administered once or repeatedly had. no

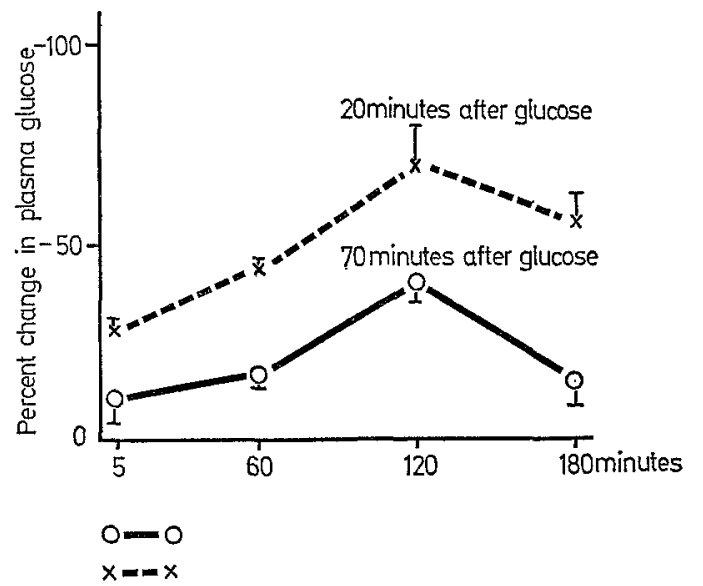

Fig. 2. Decrease of glucose-induced hyperglycaemia at different times after $\mathbf{n}$-butylbiguanide

Animals: Normal rats $(80-100 \mathrm{~g})$ had been starved $24 \mathrm{~h}$ prior to the administration of the biguanide. Abscissa: Time elapsed between the administration of n-butylbiguanide (1000 $\mu \mathrm{mol} / \mathrm{kg}$ per os $)$ and glucose $(0.8 \mathrm{~g} / \mathrm{kg}$ per os $)$. Ordinate: Change in plasma glucose (mean \pm S.E.M.; $N=5$ ) in percent of controls not pretreated with biguanide

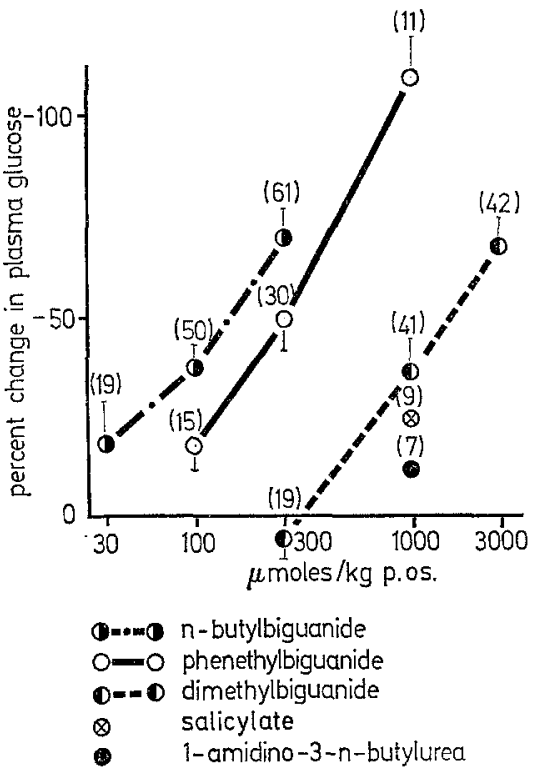

Fig. 3. Decrease of glucose-induced hyperglycaemia by biguanides in the normal rat

Animals: From rats (number in brackets; $180-220 \mathrm{~g}$ ) food was withdrawn before the first drug administration. Abscissa: Dose of the biguanide administered orally three times $(25,17$ and $1 \mathrm{~h})$ before glucose. Ordinate: Percent change of hyperglycaemia (mean \pm S.E.M.) in comparison with the control rats 20 min after glucose administration $(0.8 \mathrm{~g} / \mathrm{kg}$ per os $)$. Significant differences $(p<$ 0.001 ):

n-butylbiguanide $300 \mu \mathrm{mol} / \mathrm{kg}$

phenethylbiguanide 300 and $1000 \mu \mathrm{mol} / \mathrm{kg}$

in comparison with equivalent doses of dimethylbiguanide significant influence on the plasma glucose (Table 1) or on the parenteral glucose tolerance (Table 4).

Refed diabetic rats with uniformly elevated plasma glucose responded to n-butylbiguanide with a signi-

Table 4. Parenteral glucose tolerance after n-butylbiguanide in the diabetic rat

\begin{tabular}{lll}
\hline $\begin{array}{l}\text { n-Butylbiguanide } \\
\text { ( } \mu \text { mol/kg } \\
\text { per os) }\end{array}$ & $\begin{array}{l}\text { Plasma glucose }(\mathrm{mg} / 100 \mathrm{ml} \pm \text { S.E.M. } \\
\text { after glucose injection. } \\
1 \mathrm{~h}\end{array}$ \\
\hline- & $321 \pm 21(17)$ & $209 \pm 20(16)$ \\
100 & $363 \pm 53(6)$ & $260 \pm 54(6)$ \\
300 & $321 \pm 24(5)$ & $265 \pm 59(5)$ \\
\hline
\end{tabular}

Animals: Diabetic rats $(180-230 \mathrm{~g})$ starved for $40 \mathrm{~h}$ one week after streptozotocin injection. Number of animals in brackets.

n-butylbiguanide: At $1 \mathrm{~h}$ prior to glucose.

Glucose load: $1.6 \mathrm{~g} / \mathrm{kg}$ i.p.

ficant decrease in plasma glucose but without a change in liver glycogen content, thereby differing from normal refed rats in which the plasma glucose remained unchanged whereas the liver glycogen decreased significantly (Table 1 ).

The hypoglycaemic effect was dependent not only on the dose of the biguanide (Fig. 4), but also on the dose of streptozotocin injected one week before, i.e. on the diabetic state (Fig. 5).

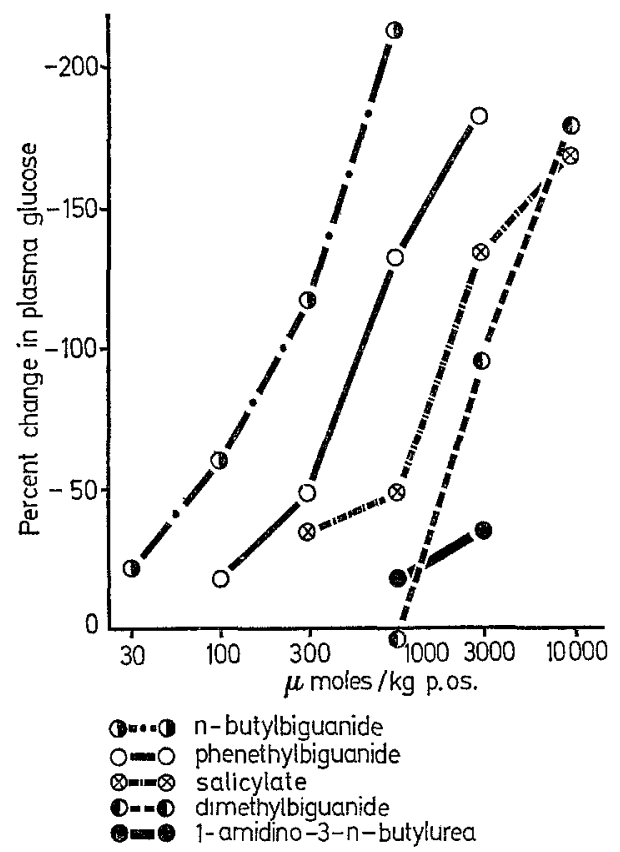

Fig. 4. Decrease of plasma glucose in the diabetic rat pretreated with biguanides and other compounds Animals : Rats $(180-230 \mathrm{~g})$, refed one week after streptozotocin injection (60 mg/kg s.c.). Abscissa: Single doses of the test compounds. Ordinate: Sum of the mean percent lowering of plasma glucose levels $(\mathrm{N}=6$ for each dose at 2,4 and $6 \mathrm{~h}$ after the biguanides) 
In diabetic rats deprived of food for only 16 hours (with variable plasma glucose values), n-butylbiguanide elicited a hypoglycaemic action in animals with high inital plasma glucose only, i.e. in rats still absorbing food (Fig. 6).

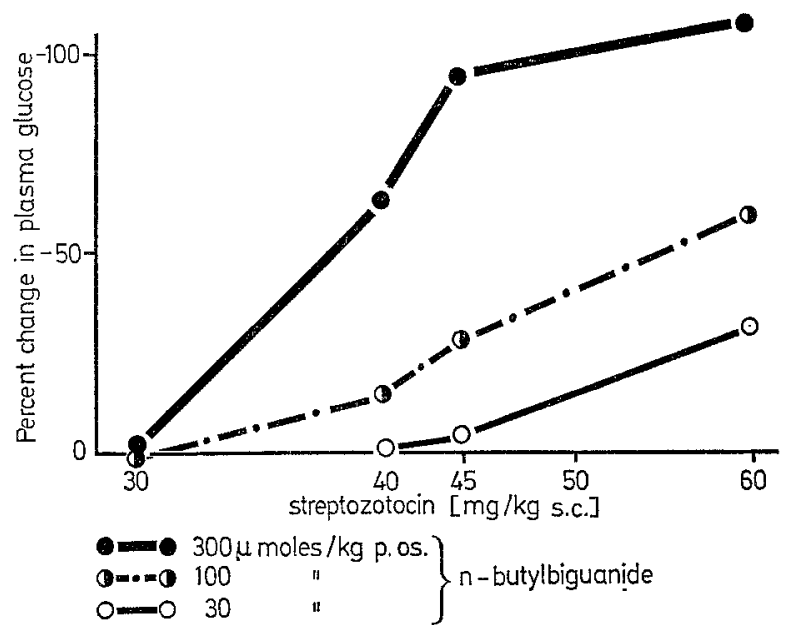

Fig. 5. Decrease of plasma glucose after n-butylbiguanide in the rat depending on the degree of streptozotocin-diabetes

Animals : Rats ( $180-230 \mathrm{~g})$, refed one week after strepto. zotocin injection. Sum of the mean percent changes of the plasma glucose levels ( $\mathrm{N}=5$ for each dose at 2,4 and $6 \mathrm{~h}$ after n-butylbiguanide)

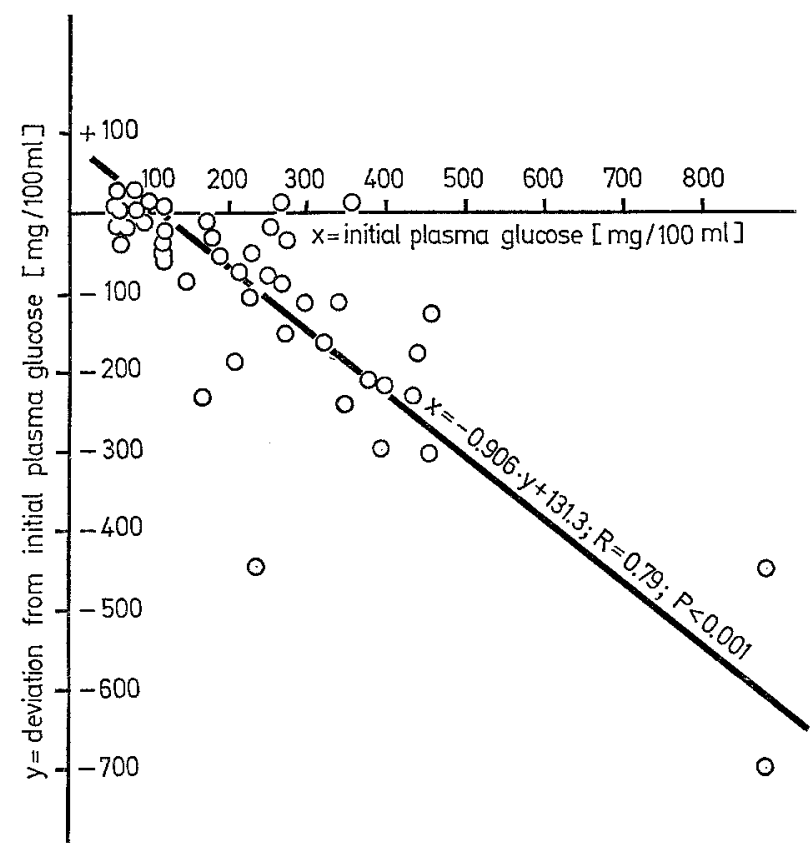

Fig. 6. Correlation between initial plasma glucose level and its depression by $n$-butylbiguanide in diabetic rats Animals: Rats $(180-230 \mathrm{~g})$ starved for $16 \mathrm{~h}$ one week after streptozotocin injection $(60 \mathrm{mg} / \mathrm{kg}$ s.c.). Abscissa: Initial plasma glucose level (blood of tail-vein) Ordinate: Individual deviation from initial plasma glucose level $2 \mathrm{~h}$ after intubation of $300 \mu \mathrm{mol} / \mathrm{kg}$ of $\mathrm{n}$-butylbiguanide
B. Effect of biguanides, salicylates and 1-amidino3-n-butylurea on glucose absorption in the isolated intestine

1. Pretreatment of Intact Rats. In everted intestinal sacs obtained from normal rats after pretreatment with n-butylbiguanide (per stomach tube) the glucose transport was inhibited. This effect appeared very rapidly, was diminished at $6 \mathrm{~h}$ and vanished at $16 \mathrm{~h}$ after the drug administration (Table 5). The ad-

Table. 5. Time course of inhibition of intestinal glucose transport after pretreatment in vivo of normal rats with $n$ butylbiguanide

\begin{tabular}{ll}
\hline $\begin{array}{l}\text { Hours after n-butylbigua- } \\
\text { nide }\end{array}$ & Percent inhibition \\
& \pm S.E.M. \\
\hline 1 & $99 \pm 16$ \\
3 & $95 \pm 32$ \\
6 & $66 \pm 10$ \\
16 & $1 \pm 8$ \\
24 & $0 \pm 5$ \\
\hline
\end{tabular}

Animals: Rats $(200-230 \mathrm{~g} ; \mathrm{N}=3)$ starved for $72 \mathrm{~h}$, Everted intestinal sacs were prepared at times (first column) after intubation of n-butylbiguanide $(300 \mu \mathrm{mol} /$ $\mathrm{kg}$ ) or of $0.9 \% \mathrm{NaCl}$ respectively. The inhibition of in. testinal glucose transport was calculated from the difference observed between tissue obtained from treated and control rats (second column).

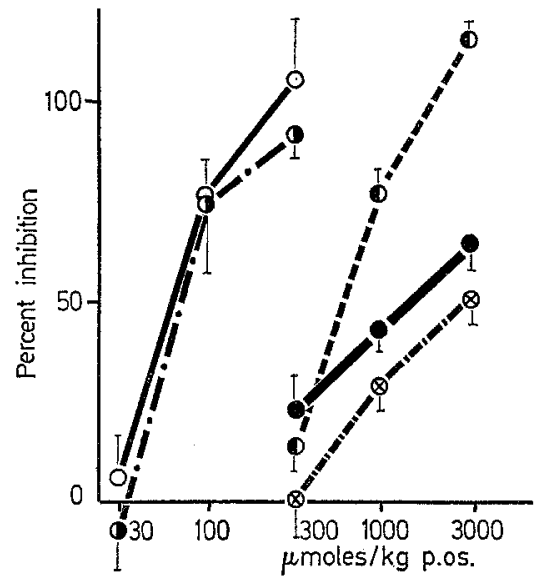

$$
\begin{array}{ll}
0=0 & \text { phenethylbiguanide } \\
-0 & n \text {-butylbiguanide } \\
-1-\text { amidino }-3-n-\text { butylurea } \\
0=0 \text { salicylate } \\
0=0 \text { dimethylbiguanide }
\end{array}
$$

Fig. 7. Inhibition of glucose transport in intestinal sacs of rats pretreated with different doses of various drugs Animals: Rats $(200-230 \mathrm{~g} ; \mathrm{N}=3)$ starved for $72 \mathrm{~h}$. Abscissa: Doses of the drugs administered $2 \mathrm{~h}$ before the preparation of everted intestinal sacs. Ordinate: Percent inhibition (mean \pm S.E.M.) of glucose transport (in comparison with control glucose transport). Significant differ* ences $(p<0.001)$ : n-Butylbiguanide and phenethylbiguanide $(300 \mu \mathrm{mol} / \mathrm{kg})$ in comparison with equimolar doses of all the other test compounds. Dimethylbiguanide (1000 and $3000 \mu \mathrm{mol} / \mathrm{kg}$ ) in comparison with equimolar doses of 1-amidino-3-n-butylurea and sodium salicylate 
ministration of other biguanides, sodium salicylate and 1-amidino-3-n-butylurea to intact normal rats before the experiment affected the glucose transport similarly (Fig. 7).

2. Addition of Drugs in vitro. After addition of the drugs to the incubation medium of everted intestinal sacs, inhibition of glucose transport was observed at drug concentrations ranging from $1.10^{-4} \mathrm{M}$ to $3.10^{-2} \mathrm{M}$ with the following order of potency: phenethylbiguanide $>$ n-butylbiguanide $=1$-amidino-3-nbutylurea $>>$ dimethylbiguanide $=$ salicylate $($ Fig. 8).

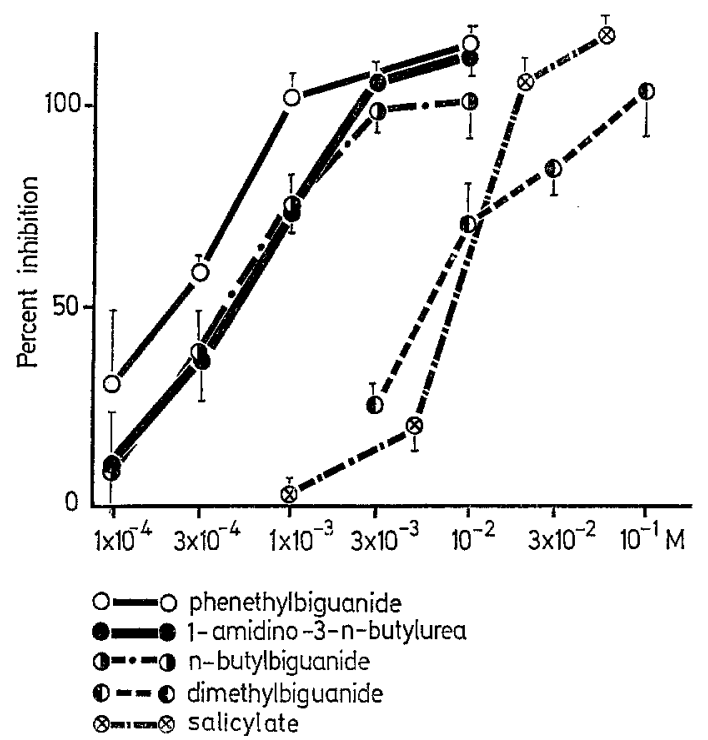

Fig. 8. Inhibition of intestinal glucose transport by various drugs in vitro

Animals: Rats $(200-230 \mathrm{~g})$ starved for $72 \mathrm{~h}$. Abscissa: Concentration of the test compounds in the mucosal medium (glucose concentration on both sides of the everted sacs: $50 \mathrm{mg} / 100 \mathrm{ml}$ ). Ordinate: Percent inhibition (mean \pm S.E.M.) of glucose transport (in comparison with control glucose transport). Significant differences $(p<$ 0.001 ): sodium salicylate at 1 and $5 \mathrm{mmol} / \mathrm{l}$ and dimethylbiguanide at $3 \mathrm{mmol} / \mathrm{l}$ in comparison with equimolar con. centration of all the other test compounds; dimethylbiguanide at $10 \mathrm{mmol} / \mathrm{l}$ in comparison with equimolar con. centrations of n-butyl- and phenethylbiguanide

\section{Discussion}

1. Peripheral glucose utilization. In normal starved rats the parenteral injection of $n$-butylbiguanide (e.g. $3 \times 300 \mu \mathrm{mol} / \mathrm{kg}$ ) caused severe hypoglycaemia, and frequently death of the animals if no glucose was administered. Nevertheless, the tolerance to intraperitoneally injected glucose showed no improvement under these extreme conditions (Fig. 1, and Table 2 and 3). The hypoglycaemia may thus be attributed to a fatal decrease in hepatic glucose production (Altschult and Krüger, 1968; Jangaard et al., 1968) rather than to an increased peripheral utilization. It is unlikely that the extremely low figure of $K<0.5$
(Table 3) represents the true coefficient of glucose assimilation because of a possible delay in glucose absorption from the peritoneum (Fig. 1). Nevertheless, the glucose tolerance was certainly not improved, and therefore this hypoglycaemic effect can hardly be relevant to the therapeutic effects of biguanides.

A dose of $300 \mu \mathrm{mol} / \mathrm{kg}$ of $\mathrm{n}$-butylbiguanide administered by stomach tube to fasting normal or streptozotocin-diabetic rats proved to be neither hypoglycaemic nor toxic. Again using the parenteral glucose tolerance as a criterion, no indication for an increased peripheral glucose utilization could be detected, even after three applications within $11 / 2$ days (Fig. 1 and Table 4). The hypoglycaemic inefficiency of enteral biguanide administration may be due to the fact that the drug levels in the liver are smaller after oral than after intraperitoneal administration. Only excessive and again lethal oral doses seem to produce similar hypoglycaemic effects (Beckmann, 1968).

2. Inhibition of intestinal absorption. In the normal starved rat, as in healthy man (Czyzyk et al., 1968; Gomez et al., 1969; Hollobaugh et al., 1970; Pereira et al., 1967), the hyperglycaemia induced by oral glucose administration was decreased after a single or repeated pretreatment with n-butylbiguanide (Fig. 1). This fact suggests that, also in the rat, biguanides act on the plasma glucose at least in part by inhibiting the intestinal absorption.

Krüger and coworkers (1970) demonstrated an inhibition of intestinal glucose transport after oral administration of phenethylbiguanide to normal rats. This could be confirmed in the present experiments. In addition, an inhibition of glucose transport was found after intubation of other biguanides and of salicylate (Fig. 7). These compounds also inhibit intestinal glucose transport when added to everted sacs of rat intestine in vitro (Fig. 8).

In streptozotocin-diabetic rats the hypoglycaemic action of biguanides was dependent on the feeding state of the animals. After $16 \mathrm{~h}$ of starvation the appreciable differences in plasma glucose levels of these polyphagic rats (Steiner et al., 1970) may be attributed to variable quantities of food remaining in the digestive tract (Renold, personal communication and our own observations). Several observations indicate that in these animals biguanides may act more or less exclusively by inhibiting intestinal absorption:

- After $16 \mathrm{~h}$ of starvation, the effect of $\mathrm{n}$-butylbiguanide on plasma glucose was found to be correlated linearly with the plasma glucose level before biguanide treatment (Fig. 6). The plasma glucose level may, in turn, be regarded as reflecting essentially the state of absorption.

- After $40 \mathrm{~h}$ of starvation at almost normal plasma glucose levels biguanides did not influence glycaemia (Table 1).

- In refed, fully diabetic rats, exhibiting extreme hyperglycaemia, a pronounced hypoglycaemic 
action of biguanides could be noted consistently (Table 1).

It is possible, however, that other factors (secondary to the feeding state or the state of absorption) are responsible for the effectiveness of biguanides in refed streptozotocin-diabetic rats. A direct action of biguanides on the insulin-independent utilization of glucose at elevated levels of plasma glucose, seems not to be involved because biguanides did not affect the parenteral glucose tolerance in streptozotocindiabetic rats (Table 4). It remains a matter of further investigation whether biguanides influence the increased production of glucagon in these animals (Steiner et al., 1970).

The oral biguanide doses required in order to reduce hyperglycaemia by $50 \%$ in the rat in vivo (Table 6 ), were considerably lower than those reported to cause hypoglycaemia in tests without glucose administration (Beckmann, 1968). Biguanides accumulate in certain tissues, including intestine (Wick et al., 1960), even after parenteral injection into experimental animals (Hall et al., 1968). For this reason the drug concentration within the intestinal tissue may be expected to prove similar to that required for the inhibition of glucose transport in vitro.

On the strength of tissue distribution studies, for instance of phenethylbiguanide in the rat (Hall et al., 1968), the intestinal drug level should be approximately $5 \times 10^{-3}$ to $5 \times 10^{-4} \mathrm{~mol} / \mathrm{kg}$ wet tissue after the parenteral administration of $100-1000 \mu \mathrm{mol} / \mathrm{kg}$ of the drug. In vitro, a 50 percent inhibition of glucose transport could in fact be achieved in the presence that salicylate, which has been used at high therapeutic dose levels as an antidiabetic agent and which is known to interfere also with energy-yielding processes (Brody, 1956), behaves similarly to biguanides in the experiments reported here.

The biguanide doses applied in human therapy are low in comparison with those used in the present experiments. The rat, however, is one of the species least sensitive to the hypoglycaemic action of biguanides (Beckmann, 1968). This is attributed to the fact that, in the case of phenethyl- and n-butylbiguanide at least, a conversion into inactive metabolites takes place more rapidly than in the human (Beckmann, 1968b). In spite of the species difference in sensitivity, the relative potency being fairly constant in the various rat experiments (Table 6), is similar to the relative potency of these drugs in the diabetic human. The higher potency in vitro of phenethylbiguanide and the lack of activity of 1-amidino-3-nbutylurea in vivo may be due to differences in absorption and/or metabolism in the intact animal.

3. Involvement of insulin. In streptozotocin-diabetic rats, the insulin content of the pancreas was reported to be only about five percent of the normal value one week after the intravenous injection of $65 \mathrm{mg} / \mathrm{kg}$ (Junod et al., 1969). In the rats used in the present experiments, $60 \mathrm{mg} / \mathrm{kg}$ s.c. of synthetic streptozotocin proved to be the maximum diabetogenic dose. After one week these animals had low levels of plasma immunoreactive insulin (Stauffacher, unpublished results), and did not respond to an insulin secretagogue (e.g. tolbutamide; Lorch, unpublished observation).

Table 6. Comparison of the biguanide doses producing half maximal effects

\begin{tabular}{|c|c|c|c|c|c|c|c|c|}
\hline & \multirow{2}{*}{\multicolumn{6}{|c|}{ In vivo }} & \multirow{2}{*}{\multicolumn{2}{|c|}{ In vitro }} \\
\hline & & & & & & & & \\
\hline & \multicolumn{2}{|c|}{$\begin{array}{l}\text { Normal rat } \\
\text { Hyperglycaemia }\end{array}$} & \multicolumn{2}{|c|}{$\begin{array}{l}\text { Intestinal glucose } \\
\text { transport }\end{array}$} & \multicolumn{2}{|c|}{$\begin{array}{l}\text { Strept. diab. rat } \\
\text { refed } \\
\text { Hyperglycaemia }\end{array}$} & \multicolumn{2}{|c|}{$\begin{array}{l}\text { Normal rat } \\
\text { Intestinal glucose } \\
\text { transport }\end{array}$} \\
\hline & $\begin{array}{l}\mu \mathrm{mol} / \mathrm{kg} \\
(3 \times)\end{array}$ & $\begin{array}{l}\text { Relative } \\
\text { Potencyb }\end{array}$ & $\mu \mathrm{mol} / \mathrm{kg}$ & $\begin{array}{l}\text { Relative } \\
\text { Potency } b\end{array}$ & $\mu_{(1 \times)^{\mathrm{a}}}$ & $\begin{array}{l}\text { Relative } \\
\text { Potencyb }\end{array}$ & $\mu \mathrm{mol} / \mathrm{l}$ & Relative \\
\hline n-Butylbiguanide & 150 & 100 & $\widehat{62}$ & 100 & 360 & 100 & 410 & 100 \\
\hline Phenethylbiguanide & 300 & 50 & 68 & 91 & 950 & 37 & 220 & 200 \\
\hline Dimethylbiguanide & 1500 & 10 & 580 & 11 & 2780 & 13 & 5100 & 8 \\
\hline Salicylate & 2000 & 8 & 3000 & 2 & 5150 & 7 & 8160 & 5 \\
\hline
\end{tabular}

a calculated from an average decrease of $50 \%$ towards starvation level

$\mathrm{b}$ n-butylbiguanide $=100$

of $2.2 \times 10^{-4} \mathrm{M}$ phenethylbiguanide (Fig. 8). After the oral administration of biguanides even higher intestinal tissue levels are to be expected. Accordingly, equimolar doses of biguanides have a stronger effect on hyperglycaemia after oral administration than after intraperitoneal injection (Table 2). Therefore, in the intestinal cells, in contrast to peripheral tissue cells, more than $10^{-3} \mathrm{M}$ biguanide may in fact oceur. At this concentration phenethylbiguanide, for instance, has been shown to inhibit succinate oxidation in isolated. mitochondria (Schäfer, 1963). It is interesting to note
If insulin were involved in the mechanism of biguanide action in refed streptozotocin-diabetic rats it would be hard to explain the decrease in the effect of biguanides with decreasing streptozotocin doses, i.e. at increasing amounts of circulating insulin (Fig. 5). Refed, nondiabetic rats, finally, do not respond to biguanides with a decrease in plasma glucose but with a decrease in liver glycogen. Glycogenolysis may be induced in order to compensate for a temporary inhibition of glucose influx from the intestine (Table 1).

On the other hand, there are two observations 
which cannot be explained by a biguanide-mediated inhibition of intestinal absorption only. At first, a mere decrease in the rate of intestinal glucose transport may result in a delayed peak of plasma glucose after a glucose load but there should be no change of the cumulative hyperglycaemia. In fact, the time of maximum hyperglycaemia was unchanged and the cumulative hyperglycaemia was significantly decreased (Fig. 1, Table 2). This means that biguanide pretreatment must have caused a decrease in the influx of glucose from the intestinal tract as well as a decrease in the total amount of glucose before or after absorption. Similar observations have been made in man (Gomez et al., 1969; Hollobaugh et al., 1970) and dog (Czyzyk et al., 1968) after oral glucose loading. Secondly, in vivo the inhibition of the intestinal glucose transport was fully established at about one hour after n-butylbiguanide (Table 5), whereas the effect on glucose-induced hyperglycaemia was maximal at about two hours after intubation of this drug (Fig. 2). Both these phenomena indicate that, besides the effect of biguanide on intestinal absorption, another effect (which may be secondary also with respect to time) seems to be required for the full action of these drugs. Presumably, this secondary effect consists in the action of enteral factors closely related to the inhibition of intestinal transport by biguanides (Berger, 1969), because it could be observed only after oral glucose administration or in a state of active absorption. However, direct efferts of biguanides on the liver metabolism (Willms, 1968) cannot be ruled out at present.

In conclusion, a fair correlation between the inhibition of the intestinal glucose transport by various antidiabetic biguanides or salicylate and the suppression of the hyperglycaemia after oral glucose administration found in the normal rat points to a causative relationship between both effects. The smaller cumulative hyperglycaemia after pretreatment with n-butylbiguanide, and the time lag between maximal inhibition of intestinal transport and of hyperglycaemia, suggest, however, additional mechanisms of biguanide action which may be closely related to the primary effect on intestinal tissue.

Acknowledgement. I wish to thank Dr. W. Berger, Dr. K.F. Gey and Prof. A.E. Renold for stimulating discussions and Dr. W. Stauffacher for the performance of insulin immunoassays. I also wish to thank Mrs. I. Beyeler and Miss A. Lippok for technical assistance.

\section{References}

Altschult, R.A., Krüger, F.A.: Inhibition of hepatic gluconeogenesis in guinea pig by phenformin. Ann. N.Y. Acad. Sci. 148, 612-622 (1968).

Beckmann, R.: Zur Pharmakodynamik der Biguanide. 2. Internationales Biguanid-Symposium, Düsseldorf, Maj 1967, Stuttgart: Thieme 1968.

- The fate of biguanides in man. Ann. N.Y. Acad. Sci, 148, 820-832 (1968b).

Berger, W.: Die intestinale Wirkung von Dimethylbi- guanid. 3.Internationales Biguanid-Symposium, Rimini, Oktober 1968 (im Druck).

- Vues actuelles sur le mechanisme d'action des biguanides. Med. et Hyg. 27, 1034-1038 (1969).

Biro, L., Banyasz, T., Kovacs, M.B., Bajor, M. : Die Wirkung des Phenyläthylbiguanids auf die Glucoseresorp. tion. Klin. Wschr. 39, 760-762 (1961).

Brody, T.M.: Action of sodium salicylate and related compounds on tissue metabolism in vitro. J. Pharmacol. 117, 39-51 (1956).

Butterfield, W.J.H., Whichelow, M.J.: The hypoglycemic action of phenformin. Effect of phenformin on glucose metabolism in peripheral tissues. Diabetes 11, $282(1962)$.

- Garatt, C.J., Whichelow, M.J.: Peripheral hormone action: Studies on the clearance and effect of $\mathrm{I}^{\mathbf{1 3 1}}$ isoinsulin in the peripheral tissues of normal acromegalic and diabetic subjects. Clin. Sci. 24, 331-341 (1963).

Creutzfeldt, W., Söling, H.D., Zarday, Z.: The combined use of insulin, tolbutamide and biguanides in the treatment of diabetes mellitus. Metabolism 12, 264-276 (1963).

Czyzyk, A., Lawecki, J.: Verlauf von Belastungsproben mit Insulin, Tolbutamid und Glucose beim Diabetes mellitus unter Phenyläthylbiguanid-Behandlung. Diabetologia 1, 80 (1965).

- - Sadowski, J., Ponikowska, I., Szczepanik, Z. : Effect of biguanides on intestinal absorption of glucose. Diabetes 17, 492-498 (1968).

Daweke, H., Bach, I.: Experimental studies on the mode of action of biguanides. Metabolism 12, 319-332 (1963).

Ditschuneit, H., Hoff, F.: Zum Problem des Wirkungs. mechanismus blutzuckersenkender Guanidin-Derivate. Now Istanbul Contribution to Clinical Science 7, 106111 (1964).

Gomez, F., Büber, V., Felber, J.P.: Veränderungen der Glucosetoleranz und des Insulinspiegels bei gesunden Menschen nach Gabe von $\mathrm{N}_{1}$-Butyl-Biguanid in RetardForm. Klin. Wschr. 47, 1313-1317 (1969).

Good, C.A., Kramer, H., Somogyi, M. : The determination of glycogen. J. biol. Chem. 100, 485-491 (1933).

Hall, H., Ramachander, G., Glassman, J.M.: Tissue distribution and excretion of phenformin in normal and diabetic animals. Ann. N.Y. Acad. Sci. 148, 601-611 (1968).

Hardegger, E., Meier, A., Stoss, A.: Eine präparative Synthese von Streptozotocin. Helv. chim. Acta 52, $2555-2560$ (1969).

Hollobaugh, S.L., Rao, M.B., Krüger, F.A.: Evidence for significant "non-peripheral" effects of phenformin on glucose metabolism in man. Clin. Res. 15, 428 (1967).

_ - - Studies on the site and mechanism of action of phenformin. I. Evidence for significant "non-peripheral" effects of phenformin on glucose metabolism in normal subjects. Diabetes 19, 45-49 (1970).

Jangaard, N.O., Pereira, J.N., Pinson, R.: Metabolic effects of the biguanides and possible mechanism of action. Diabetes 17, 96-104 (1968).

Johnson, J.A., Nash, J.D., Fusaro, R.M.: An enzymatic method for the quantitative determination of glycogen. Anal. Biochem. 5, 379-387 (1963).

Junod, A., Lambert, A.E., Stauffacher, W., Renold, A. E. : Diabetogenic action of Streptozotocin: Relationship of dose to metabolic response. J. clin. Invest. 48, 2129-2139 (1969).

Krüger, F.A., Skillman, T. G., Hamwi, G.J., Grubbs, R. C., Danforth, N.: Mechanism of action of hypoglycemic guanidine derivatives. Diabetes 9, 170-179 (1960).

- Altschuld, R.A., Hollobaugh, S.L., Jewett, B.: Studies on the site and mechanism of action of phenformin. IT. Phenformin inhibition of glucose transport by rat intestine. Diabetes 19, $50-52(1970)$.

Logan, J.E., Haight, D.E.: Enzymatic determination of 
glucose in urine by automation following rapid removal of inhibitors by ion-exchange resin. Clin. Chem. 11, $367-377 \quad(1965)$.

Pereira, V.G., Wajchenberg, B.L., Shnaider, J.: Mechanism of action of phenethylbiguanide in normal sub. jects. Diabetes 16, 302-305 (1967).

Somogyi, M. : Determination of blood sugar. J. biol. Chem. 160, $69-73(1945)$.

Schäfer, G.: Oligomycinähnlicher Effekt von Biguaniden. Biochem. Z. 339, 46-52 (1963).

Staub, H.: Über Synthalin. Verh. dtsch. Ges. Verdau.- u. Stoffwechselkr. (Leipzig) 7, 290-301 (1928).

Steiner, H., Oelz, O., Froesch, E.R., Weber, E.: Reaktionen des Pankreas bei Streptozotocindiabetes, insbesondere der Glucagonzellen. Schweiz. med. Wschr. 100, $595-596(1970)$ and own observations.

Watson, D.: Enzymatic determination of glucose and easily hydrolysable glucose esters in blood. Anal. Bio. chem. 3, 131-144 (1962).

Wick, A.N., Stewart, Ch. J., Serif, G.S.: Tissue distribu- tion of $\mathrm{C}^{14}$-labeled beta-phenethylbiguanide. Diabetes 9, $163-169$ (1960)

Williams, R.H., Tyberghein, J.M., Hyde, P.M., Nielsen, R.L.: Studies related to the hypoglycemic action of phenethylbiguanide. Metabolism 6, 311-319 (1957).

Willms, B., Moshagen, D., Söling, H.D.: Experimentelle Untersuchungen zur Wirkung von Buformin auf die isolierte perfundierte Leber der Ratte. 2. Internationales Biguanid-Symposium, Düsseldorf, Mai 1967. Stuttgart: Thieme 1968.

Wilson, T.H., Wiseman, G.: Metabolic activity of the small intestine of the rat and the golden hamster (Mesocricetus auratus). J. Physiol. 123, 126-130 (1954).

Dr. E. Lorch

Dept. of Experimental Medicine Hoffmann-La Roche \& Co. CH-4000 Basle Switzerland 